\title{
DECOMPOSITION OF UNEMPLOYMENT: THE CASE OF THE VISEGRAD GROUP COUNTRIES
}

\author{
Michal Tvrdon̆
}

\section{Introduction}

In labour economics, unemployment is seen as a phenomenon when there is a market surplus of supplied amount of labour in the market. In other words, unemployment occurs when a person who is actively searching for employment is unable to find a job. Unemployment is often used as a measure of economy's performance. The most often used measure of unemployment is the unemployment rate - usually the number of unemployed persons that are actively searching for employment divided by the number of people in the labour force.

However, the problem of unemployment is very complex because there are numerous ways how to decompose unemployment (e.g. voluntary vs. involuntary; short-term vs. longterm or national vs. regional). According to McConnell, Brue and Macpherson (2009) the overall rate of unemployment does not distinguish between the individuals who are experiencing short unemployment spells and those who are going through long periods of unemployment. In these boundaries, we have to look at this phenomenon as movements of the labour force between categories of labour force statute such as population not in the labour force, unemployed or employed labour force. There is a measurable stock of people in each of these three categories. But these stocks are simultaneously being depleted and replenished by numerous flows into and out of each category. Changes in the rates of these flows can significantly affect the overall unemployment rate.

In the context of this paper, it is important to distinguish between three essential types of unemployment: (i) frictional unemployment; (ii) cyclical unemployment; and (iii) structural unemployment. The first one is related to a situation that not all active job searchers will have yet found or accepted employment, and not all employers will have yet filled their job vacancies. This type of unemployment consists of search unemployment and wait unemployment. The second one is given by cyclical changes in economic performance. It contributes to decreasing in overall unemployment during the period of economic growth and to its increasing during the period of economic downturns. The last one is a part of the national natural rate of unemployment which is associated with economic performance at the level of potential output; or in other words, the unemployment rate that persists regardless of the rate of inflation. Orlandi (2012) defines structural unemployment as 'natural' rate of unemployment that the economy would settle at in the long run in the absence of shocks. Its level is determined by institutional factors and fiscal measures (unemployment benefits, tax rates) which influence the reservation wage. According to Andersson et al. (2015) in many parts of Europe, such structural unemployment consists of falling demand for workers with few or obsolescent skills combined with labour market rigidities and/or living costs that make such workers unemployable in the absence of migration to regions with lower costs and wages.

As written above, there is no doubt that the business cycle influences unemployment. However, the impact of economic downturns on structural unemployment will depend on many factors. By weakening the labour market situation, economic downturns could lead to an increase in structural unemployment; through hysteresis effects whereby the path of actual unemployment influences structural unemployment (for more see Furceri and Mourougane, 2009). The level of structural unemployment reflects many different aspects, i.e. the wage bargaining system, the unemployment benefit system including 
eligibility and availability rules, tax rates, a scale and character of active labour market policy's measures, hiring and firing rules, the educational composition of labour force, the intensity of product market competition, etc.

The aim of the paper is to decompose unemployment in Visegrad group countries (Czech Republic, Hungary, Poland and Slovakia) and to compare two selected approaches to decomposition - (i) the first one is based on the Hodrick-Prescott filter; (ii) the second one is based on Kalman filter and is often used by OECD or IMF. Moreover, European Commission employed Kalman filter to estimation nonaccelerating wage rate of unemployment (NAWRU). The paper is structured as follows: (i) in the first part, the paper deals with theoreticalmethodological background; (ii) the second part refers to the methodology of unemployment's decomposition; (ii) the third part is focused on empirical results - we estimated and compared two main structural unemployment's estimating methods; and the last part concludes.

\section{Literature Review}

The concept of structural unemployment is related to the fact, that the rate of inflation can be high - and increasing - even though the rate of unemployment is relatively high. Structural unemployment might be defined as the level of unemployment compatible with stable inflation in a medium-term perspective. This definition implies that macroeconomic policy cannot permanently reduce unemployment below the structural level. This somewhat pragmatic definition of structural unemployment is not synonymous with the theoretical term NAIRU (nonaccelerating inflation rate of unemployment), although closely related (Gersing, 1997). There is much confusion and disagreement among economists concerning the definitions of the natural rate of unemployment and the NAIRU. For some economists these two terms are interchangeable. However, recent studies indicated that the term NAIRU and the natural rate of unemployment are not substitutable (Claar, 2005).

The concept of the natural rate of unemployment (NRU) represents the hypothetical unemployment rate consistent with aggregate production being at the "long-run" level. This level is consistent with aggregate production in the absence of various temporary frictions such as incomplete price adjustment in the labour and goods markets. The natural rate of unemployment therefore corresponds to the unemployment rate prevailing under a classical view of determination of an activity. It is mainly determined by the economy's supply side, and hence production possibilities and economic institutions. If these institutional features involve permanent mismatches in the labour market or real wage rigidities, the natural rate of unemployment may feature involuntary unemployment.

Romer (2005) argues that the development of the theory of the natural rate of unemployment came in the 1960s where economists observed that the Phillips-curve relationship between inflation and unemployment began to break down. Until then, it was widely believed that a stable negative relation between inflation and unemployment existed. This belief had the policy implication that unemployment could be permanently reduced by expansive demand policy and thus higher inflation. Nevertheless, if we look at the original Friedman's paper (1968) we do not find a clear, well-defined characterization of this concept, but rather description of some features that it should have. This resulted in the hysteresis hypothesis, which states that cyclical fluctuations in the labour market might affect the unemployment rate permanently and might lead to a long-term persistence. This means that the unemployment should be an integrated process (see Gomes, 2009).

According to Weiner (1993) when the economy is at the natural rate of unemployment, inflation tends to be constant from one year to the next. Individuals come to expect this inflation rate and base their decisions on it. Any attempt to use monetary of fiscal policy to reduce unemployment below the natural rate of unemployment ultimately results in higher inflation. Under such a scenario, aggregate demand increases, prices rise, but wages initially lag behind. As a result, firms have an incentive to hire more workers to produce more output and the unemployment rate declines. The decline in unemployment is temporary, however, because workers eventually demand higher wages. The increase in inflation, in contrast, is permanent. The central bank can set the inflation or the economic cycle. If the central bank follows the inflation variability, the society must tolerate the output gap variability. 
On the other side central bank can set the economic cycle goal. It means the central bank minimises the output gap variability.

The OECD distinguishes between a longrun structural rate of unemployment (NRU), corresponding to Friedman's original natural rate, determined by economic fundamentals, and the non-accelerating inflation rate of unemployment (NAIRU) as a short-run phenomenon. The latter may differ from the $N R U$, when structural or demand shocks occur. In general, the NAIRU is considered an extension of Friedman's natural rate when labour markets are not competitive and most of the literature overlaps the two concepts (for more see Chiarini and Piselli, 2001).

We understand structural unemployment something between pure short-run and longrun NAIRU depending on the changes in actual unemployment. According to Gersing (1997) if actual unemployment equals the structural rate and if unemployment has been constant for some time, inflation will be (approximately) constant, whereas a reduction in unemployment below the structural level will give rise to steadily increasing - or at least unsustainably high - inflation. According to Herz and Rens (2011) there are four sources of structural unemployment in the model. Each segment of the labour market is characterized by four variables: the job finding rate, which measures how hard it is for workers to find a job; the worker finding rate, which measures how hard it is for firms to find a worker; workers' surplus from having a job over being unemployed; and firms surplus of having filled position over a vacancy. In the absence of adjustment costs, worker mobility, job mobility and wage adjustment lead to equalization of labour market conditions across segments. Worker and job mobility costs, wage bargaining costs and heterogeneity in matching efficiency generate dispersion in labour market conditions and therefore structural unemployment. In addition, Orlandi (2012) distinguishes two groups of structural unemployment's determinants: (i) structural, which are features of the labour market like active labour market policies, labour taxation or unemployment benefits; and (ii) non-structural, which include changes in the real interest rate, variations in the level of technological progress and housing boombust effects.

On the other hand, Boeri and Jimeno (2015) argue that long-term trends and the long- lasting effects of the crisis on the relationship among macroeconomic variables make it more and more difficult to disentangle structural and cyclical unemployment, and, in fact, the several measures of structural unemployment, however defined, just fluctuate too much over time to qualify for being considered as structural. They also recommend using the actual unemployment rates as a reference, rather than being based on unreliable, and possibly meaningless, estimates of structural unemployment or output gaps for cross-country co-ordination in fiscal policies.

\section{Methodology}

We can find three basic estimation groups of methods how to estimate structural component of unemployment: (i) structural methods; (ii) statistical methods; (iii) the reduced-form methods. The first group is based on modelling aggregate wage and price setting behaviour in a structural form. However, according to Turner et al (2001) the derived measure of equilibrium unemployment corresponds more closely to a measure of the long-run equilibrium rate of unemployment rather than the NAIRU which commonly appears in reduced-form Phillips curve specifications. Moreover, another problem which is associated with this method is considerable difficulty in quantifying many of the relevant institutional variables (the employment protection legislation, unemployment benefits or a degree of unionisation). The second group involves purely statistical methods that focus on the actual unemployment rate and its split into structural (NAIRU) and cyclical components. According to Turner et al. (2001) the assumption behind these approaches is that, since there is no long-term trade-off between inflation and unemployment. The third approach is based on the expectation-augmented Phillips curve. This approach has the major advantage of being directly related to the definition of the NAIRU.

As seen above one of the purely statistical methods is filtering using the Hodrick-Prescott filter. According to Flek et al. (2010) this method attempts to estimate the NAIRU using purely statistical technique to directly split the not seasonally adjusted unemployment rate into cyclical and trend components, with the latter identified as the NAIRU. To estimate structural component of unemployment, it is necessary to have just the time series of the unemployment rate. The standard ANOVA 
(analysis of variance) is recommended in order to determine the presence of quarterly seasonality in the unemployment rates series. Unemployment rates usually exhibit significant seasonality. There are several methods and techniques to adjust time series, e.g. Census $\mathrm{X} 12$ and TRAMO/SEATS. The first program is produced and widely used by the U.S. Census Bureau. TRAMO (Time series regression with ARIMA noise missing observations and outliers) and SEATS (Signal extraction in ARIMA time series), was developed by Gómez and Maravall (1996). For more details to seasonal adjustment and TRAMO/SEATS method see Gómez and Maravall (1998). TRAMO preadjust the series to be adjusted by SEATS Maravall and Sánchez (2000). Both of them are officially used by the Eurostat and the Czech statistical office.

The Hodrick-Prescott methodology can be found in Němec (2008), Tasci (2012), Tvrdoň, Tuleja and Verner (2012) and Gomes (2009). This method is quite frequently used to filter the trend and the cyclical time series. The only input parameter for the optimal filter, we have to specify, is an appropriate smoothing constant $\lambda$. It is defined as the ratio of dispersion of shock causing cyclical fluctuations and shocks affecting the growth trend Hloušek and Polanský (2007).

The filter is characterized by this formula Hájek and Bezděk (2001):

$$
\operatorname{Min}\left\{\sum_{t=1}^{T}\left(U_{t}-U_{t}^{*}\right)^{2}+\lambda \sum_{t=2}^{T-1}\left[\left(U_{t+1}^{*}-U_{t}^{*}\right)-\left(U_{t}^{*}-U_{t-1}^{*}\right)\right]\right\}
$$

where $U$ denotes the seasonally adjusted unemployment rate, $U^{*}$ is the trend component of unemployment, $\lambda$ is a parameter determining the smoothness of the trend smoothing. For $\lambda=0$ the natural rate of unemployment is equal to the real unemployment rate, for $\lambda \rightarrow \infty$ the trend will be a straight line.

When choosing a value of smoothing constant $\lambda$, we then drew on generally accepted recommendations - experts consider optimal value 14,400 for monthly data, 1,600 for quarterly data and 100 for annual data (Rozmahel (2011), Gerlach and Yiu (2004), Zimková and Barochovský (2007) or Hájek and Bezděk (2001).

When we had adjusted time series we applied the Hodrick-Prescott filter to identification a trend component of unemployment. The difference between the estimated trend and the original seasonally adjusted time series represents the cyclical component of unemployment (when you turn the sign). Structural unemployment, we subsequently computed as a part of the residual of the total rate after deducting seasonal and cyclical components (Flek et al. 2010). The disadvantage of this method of estimation using the HP filter represents, according to Hájek and Bezděk (2001), the fact that the results are mainly at the end of the series somewhat skewed. In other words, it means that they tend to be least reliable at the end of the sample. However, adding a few data of forecasts to the end of the data sample has become standard practice.

If we look at the last group of methods, statespace models with Kalman filter techniques have been widely used in the recent literature to estimate the NAIRU. In this framework, the estimated NAIRU is time varying and treated as an unobserved stochastic variable: it is derived from its ability to explain inflationary developments, subject to various constraints on its evolution over time (Gianella, 2008). The simplest theoretical framework incorporating the NAIRU concept in a transparent fashion is the expectation-augmented Phillips curve, which captures a disequilibrium adjustment mechanism: inflation depends on its past values, on the tightness of the labour market and other factors potentially affecting its response to demand pressures (Fabiani and Mestre, 2000):

$$
\Delta \pi_{t}=\alpha(L) \Delta \pi_{t-1}-\beta\left(u_{t}-u_{t}^{*}\right)-\theta(L) \Delta u_{t}+\gamma(L) z_{t}+e_{t}
$$

where $\Delta$ is the first difference operator, $\pi$ is inflation, $u$ is the observed unemployment rate, $\mathrm{u}^{*}$ is the NAIRU, $\mathrm{z}$ is a vector of temporary supply shock variables, $\alpha(L), \theta(L)$ and $\gamma(L)$ are polynomials in the lag operator and $e$ is a serially uncorrelated error term with zero mean and variance $\sigma 2$.

For the Kalman filter, the Phillips curve is used directly as the only measurement equation (Boone, 2000). The state space form comprises two equations: a measurement equation and a transition equation. First, we write the Phillips curve (measurement equation) in a matrix format (according to Turner et al. 2001):

$$
y_{t}=Z X_{t}+R D_{t}+e_{t}
$$

where $\mathrm{Z}$ and $\mathrm{R}$ are vectors of parameters, $\mathrm{X}$ is 
a vector of unobserved variables (the NAIRU), while $D$ is a vector of observed exogenous variables (lagged inflation, temporary supply shocks).

Secondly, we write a transition equation (in matrix format) that specifies the time-series process generating the unobservable state variables and is given by:

$$
X_{t}=T X_{t-1}+\varepsilon_{t}
$$

where et and $\varepsilon$ are iid, normally distributed with mean zero and variances $\mathrm{Ht}=\sigma 2$ and $\mathrm{qt}=\sigma 2$. The ratio $\mathrm{qt} / \mathrm{Ht}=\mathrm{Q}$ is called the signal-to-noise ratio. $T$ is a vector of parameters.

The Kalman filter is made up of two stages: (i) the filtering procedure builds up the estimates as new information about the observed variable becomes available. If at is the optimal estimate of the state variable $\mathrm{Xt}$ (the NAIRU) and $\mathrm{Pt}$ its variance/covariance matrix, then, given at-1 and Pt-1, the Kalman filter may be written:

$$
\begin{aligned}
& a_{t+1 \mid t}=\left(T-K_{t} Z\right) a_{t \mid t-1}+K_{t}\left(y_{t}-d_{t}\right) \\
& \text { with } K_{t}=T P_{t \mid t-1} Z^{\prime} F_{t}^{-1} \text { and } F_{t}=Z P_{t \mid t-1} Z+H \\
& \text { and } P_{t+1 \mid t}=T\left(P_{t \mid t-1}-P_{t \mid t-1} Z^{\prime} F_{t}^{-1} Z P_{t \mid t-1}\right) T^{\prime}+Q
\end{aligned}
$$

These equations permit the computation of the prediction errors vt for period $t$ as:

$$
v_{t}=y_{t}-Z a_{t \mid t-1}-R D_{t}
$$

to go into the likelihood function:

$$
l_{t}=-\frac{1}{2} \log 2 \pi-\frac{1}{2} \log \left|F_{t}\right|-\frac{1}{2} v_{t} F_{t}^{-1} v_{t}
$$

The series \{at\} that maximises this function gives an optimal estimate of the one-sided NAIRU.

\section{Empirical Results}

First, we applied the Hodrick-Prescott filter (HP filter) for estimation the structural component of unemployment. To estimate the structural component of unemployment, it is necessary to have the time series of the unemployment rate - in our case the seasonally not adjusted unemployment rate. Quarterly data between the years 2000 and 2014 (60 observations per each country) obtained from Eurostat database were applied. Hence, TRAMO/SEATS method was applied to seasonal adjustment.
Figure 1 shows development of the Czech labour market. The initial quarter (1Q2000) was characterized by the high unemployment rate and the low level of unfilled jobs. The figure shows that the Czech labour market has undergone four cyclical changes during the observed period (for a detailed analysis see Tvrdoň, Tuleja and Verner 2012). The first positive cyclical influence on the total unemployment rate occurred between 2001Q1 and 2003Q1, the second one occurred from 2007Q1 to 2009Q1. The fundamental difference between these two cycles consisted of their dynamics. While shifts were minor during the first cycle, there were significant shifts during the second cycle (see Figure 1). Moreover, the latter one was caused by significant economic growth during this period which was typical for all small open and export-oriented economies. Each cycle started by gradual improvement of labour market performance. This trend was reflected by reducing unemployment and raising the number of unfilled jobs. In the next phase, after reaching the summit, the unemployment rate started to grow and the number of unfilled jobs started to decline as the consequences of the economic crisis. These phases of a business cycle were seen during 2003Q3 and 2006Q3 and the second period lasted between 2009Q2 and 2010Q2. After short improvement economic performance during year 2011, the second wave of the 2009 crisis appeared. The Eurozone went into another recession in 2012 and it caused a contraction of the main pro-growth factor - export. As a result, the unemployment rate started to rise. However, this growth was not so high in comparison with the 2009-2010 crisis. The Eurozone economy recorded a slow recovery from the recession in 2013 and this development was spilled over into the Czech economy with some delay - last data show that another improvement of labour market performance has appeared. According to Araújo and Maleček (2015) the employment rate in the Czech Republic has been heavily influenced by structural factors, whereas cyclical effects have been playing a relatively minor role. In the case of unemployment, however, the business cycle has a much greater effect on the unemployment rate in comparison with the employment rate. If we look at the estimated structural component of unemployment, we can conclude that it is the main part of total unemployment in the 
Czech Republic. Moreover, the structural unemployment rate was decreasing over time - this suggests an idea that labour market performance has improved since 2000. If we look at the pre-crisis period, we can see that the main source of a decrease in the total unemployment rate were changes in cyclical component of unemployment.

\section{Fig. 1: Decomposition of unemployment (quarterly data) - Czech Republic}

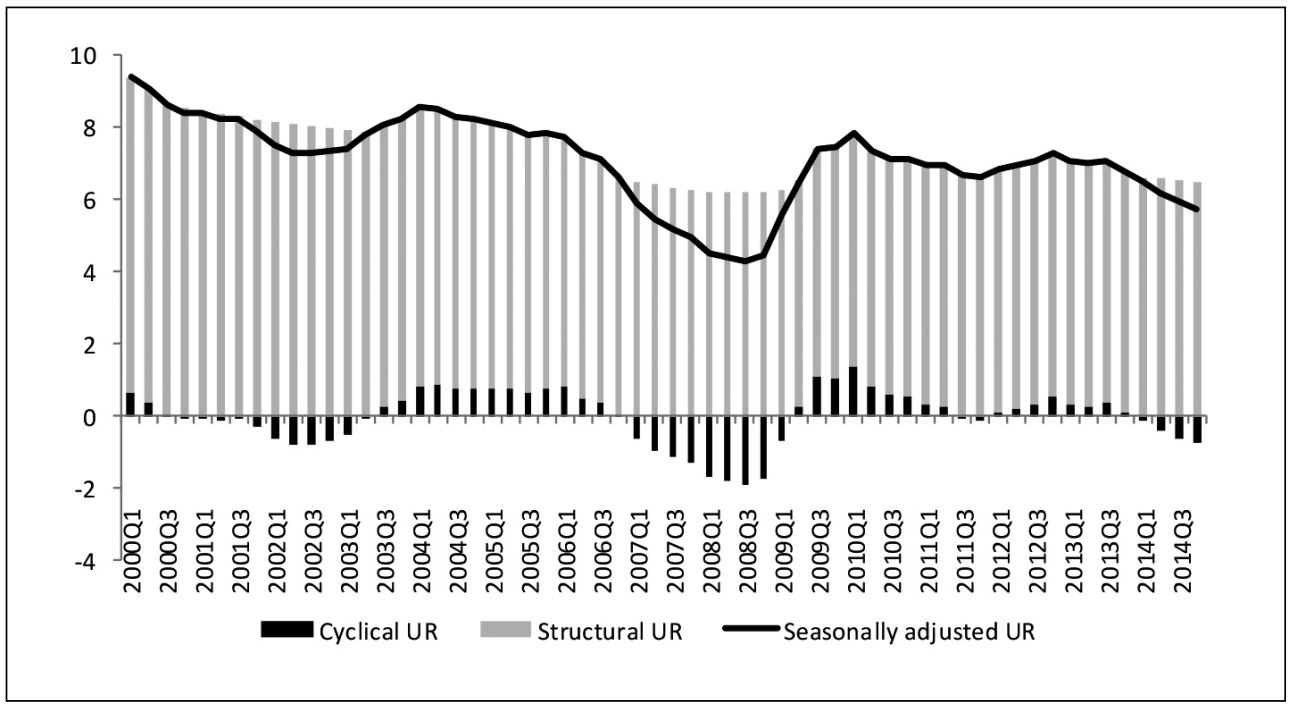

Source: Eurostat; own calculation

As well as other Visegrad group countries (V-4), Hungary was remarkably affected by the global crisis, however the Hungarian economy has been falling behind the rest of V- 4 countries. The development was different due to problems of internal nature. The Hungarian labour market can be described as rigid, though some shifts occurred during the observed period. In the first half of the observed period (until 2004), the unemployment rate was quite stable and stayed at a relatively low level. Since 2004, however, the rate of unemployment has increased and the rate of unfilled jobs has declined. Unlike other V-4 countries the subsequent development of the labour market was affected by the problems with which the economy struggled. As shown in Figure 2, the unemployment rate has increased continuously since 2008Q1, even labour market performance significantly improved in the other V-4 countries. This insufficient labour market development was influenced by a severe economic situation in the country which was caused by unstable finances, large fiscal imbalances and high government debt. Some authors (e.g. Egedy, 2012) defined the increasing level of overspending as the main problem of the Hungarian economy. According to Békesi (2011) among main problems were low economic performance of the country, its low competitiveness in international comparison, scarce resources, the small size of the domestic market, the unfavourable demographic trends, and the quantitative and structural problems of labour force. Another specific feature was the share of foreign currency loans in total loans foreign currency debt was huge in comparison with the Czech Republic and Slovakia. Given the size of fiscal imbalances, government had to raise state budget's revenues, e.g. surge in employee social contributions, value-added tax and business taxation. In the first phase of the economic crisis, the unemployment rate rose only moderately and mainly in the problematic regions. In the second phase of 
the crisis, the unemployment rose increased in all regions. Moreover, unlike other Visegrad group countries the estimated structural unemployment rate increased during the observed period (see Figure 2) - this can be explained by increased labour mismatches during the past decade. According to OECD (2014a) the main mismatch, amplified by the economic crisis and technological progress, is an oversupply of low-skilled workers, as reflected in their very low employment rate. According to Egedy (2012) the largest decline in employment occurred in the industry (construction and manufacturing). Similar to the situation in the Czech Republic and Slovakia, many jobs were lost in the automotive and electronics companies. Moreover, the cyclical component of unemployment did not have so significant effect on total unemployment until 2013. We can see remarkable positive cyclical effects starting from 2013Q1 and which have led to significant reducing unemployment - the labour market seems to be less tense in 2013 and 2014 than in previous years. According to Bakó (2014) this development can be explained by expanding car production and export, as well as the intensifying of internal demand all played an important role in the

\section{Fig. 2: Decomposition of unemployment (quarterly data) - Hungary}

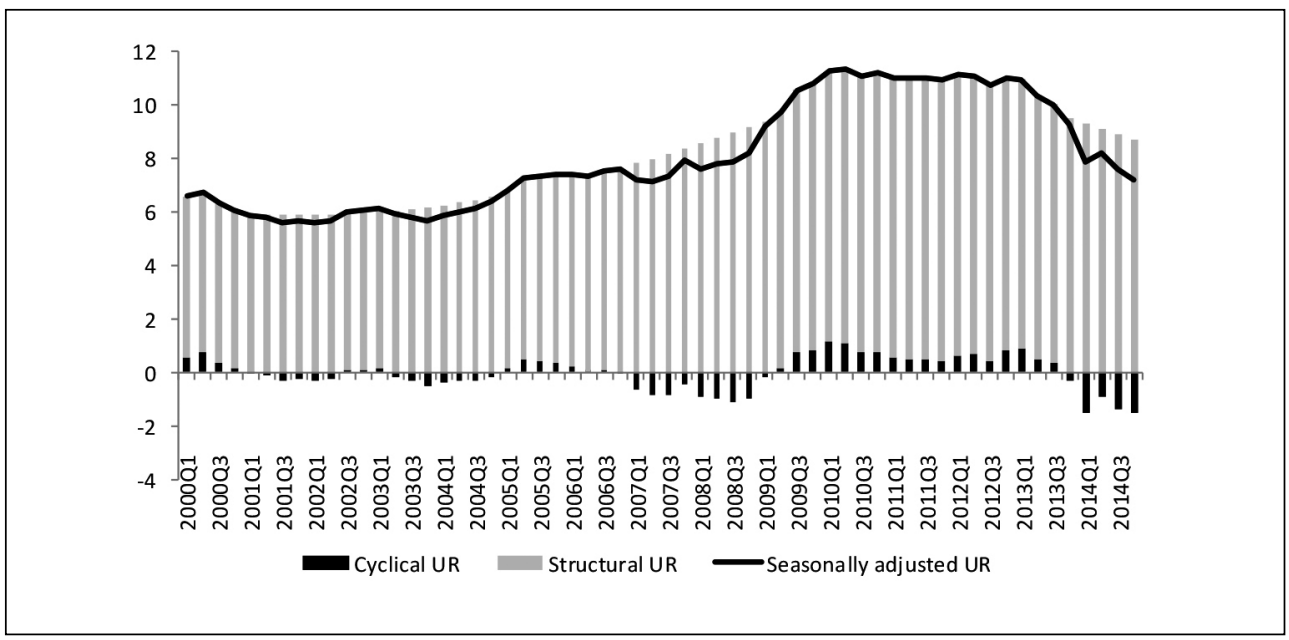

Source: Eurostat; own calculation

growth. Economic investment increased for the first time since the crisis mainly thanks to infrastructure developments financed from EU sources but household consumption also expanded underpinned by rising real wages and strengthening consumer confidence.

Polish labour market performance was worsening by increasing the unemployment rate to beyond $20 \%$ accompanied by the low rate of unfilled jobs in the first four years (see Figure 3). It has started to improve since 2004 - the unemployment rate gradually declined to a historically the lowest rate of $7 \%$ before the economic crisis. One important fact that remarkably influenced structural unemployment in Poland was the eastern enlargement in 2004 accompanied by full or partial opening of the national labour markets of "old" Member States to citizens of the New Member States (so called principle of free movement). According to Galgóczi, Leschke and Watt (2009) many workers in particular were keen to take advantage of new opportunities to earn higher wages. In Poland, for example, the number of people who took this opportunity and started to work in other Member States more than doubled between 2004 and 2007, reaching almost two million. As the result, this movement of labour force reduced pressures on the labour market, especially on the labour supply 


\section{Fig. 3: Decomposition of unemployment (quarterly data) - Poland}

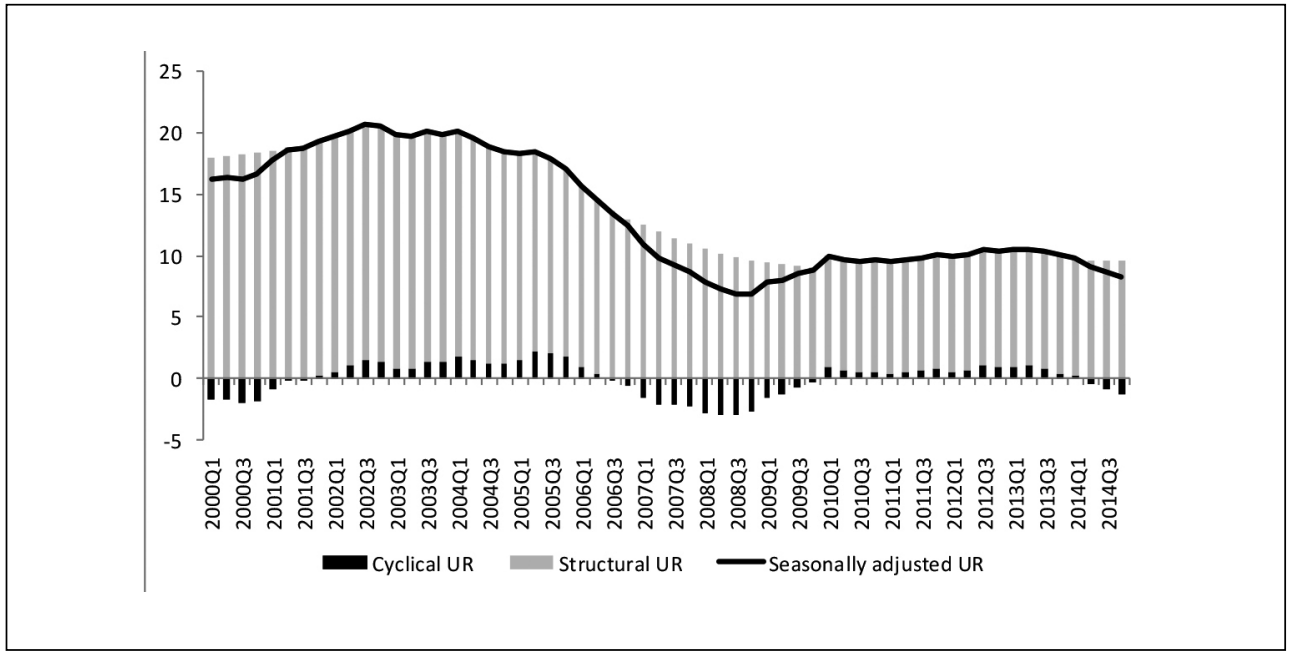

Source: Eurostat; own calculation

side and contributed to lower unemployment in Poland. Moreover, Poland has had the highest real GDP growth since 2007 among the Visegrad group and even the whole EU. According to OECD (2012) this strong performance can be explained by substantial inflows of EU funds (which have contributed to modernising transport infrastructure), stimulus from domestic macroeconomic policies (through 2010), exchange-rate depreciation and effective prudential regulation of the comparatively solid financial system. Certain signs of overheating were recorded before 2009 - this is in line with the empirical evidence that proved significant positive cyclical effects that caused the negative unemployment gap (see Figure 3). After that, like the rest of V-4 countries or other EU countries the unemployment rate started to increase again. However, growth was not so remarkable due to different development of the business cycle. Our estimations suggest that the high level of unemployment is essentially structural. In addition, according to OECD (2014b) persistently high structural unemployment is likely to have contributed to the phenomenon of widely used fixed-term contracts by weakening workers' bargaining power and prompting them to accept offers for relatively precarious jobs.

Figure 4 shows labour market development in the Slovak Republic. The initial characteristics of the Slovak labour market were similar to the Polish labour market - the high unemployment rate and a small number of unfilled job vacancies. An improvement of business environment, restructuring in banking sector and structural reforms (tax, social and labour market reforms) attracted new greenfield FDIs, which boosted potential growth of the economy as of 2004 (Sramkova 2010). The unemployment rate was decreasing significantly during the pre-crisis period. As in the Czech Republic and Poland we can see that negative cyclical effects were the main source of an increase of total unemployment rate after 2009. Estimates in Tvrdon, Tuleja and Verner (2012) suggest that there was an economy's overheating in 2008. However, the Slovak labour market was influenced by the economic recession - the unemployment rate increased remarkably and this increase was among the EU countries with the highest shift. Moreover, according to OECD (2014c) almost $40 \%$ of the unemployment increase since 2009 was concentrated in the eastern regions and long-term unemployment accounts for $70 \%$, while western regions benefit from strong economic growth and labour market performance. According to Fidrmuc et al (2013) euro adoption changed the composition of growth's drivers dramatically. Disinflation, enforced by the large output gap 


\section{Ekonomie}

Fig. 4:

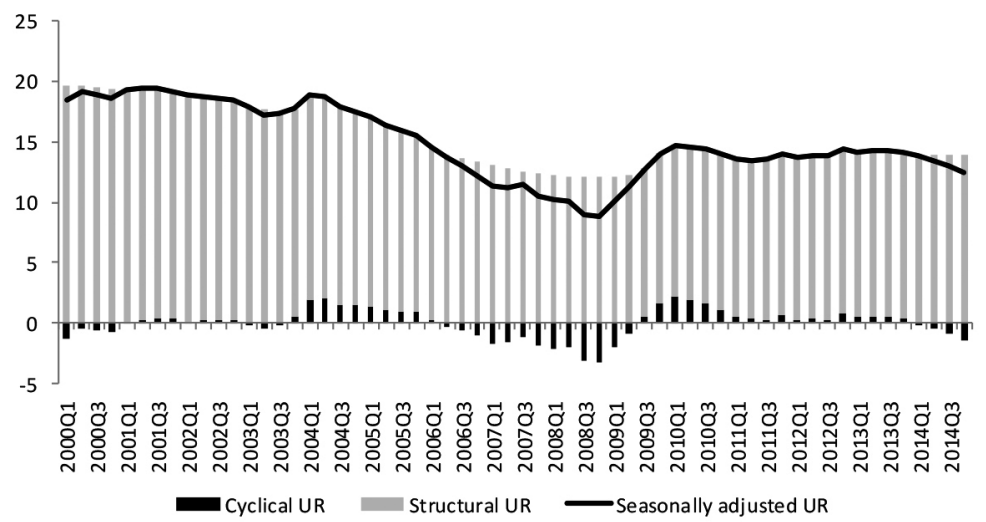

Source: Eurostat; own calculation

\section{Fig. 5: Comparison of OECD and Author's approach (annual data)}

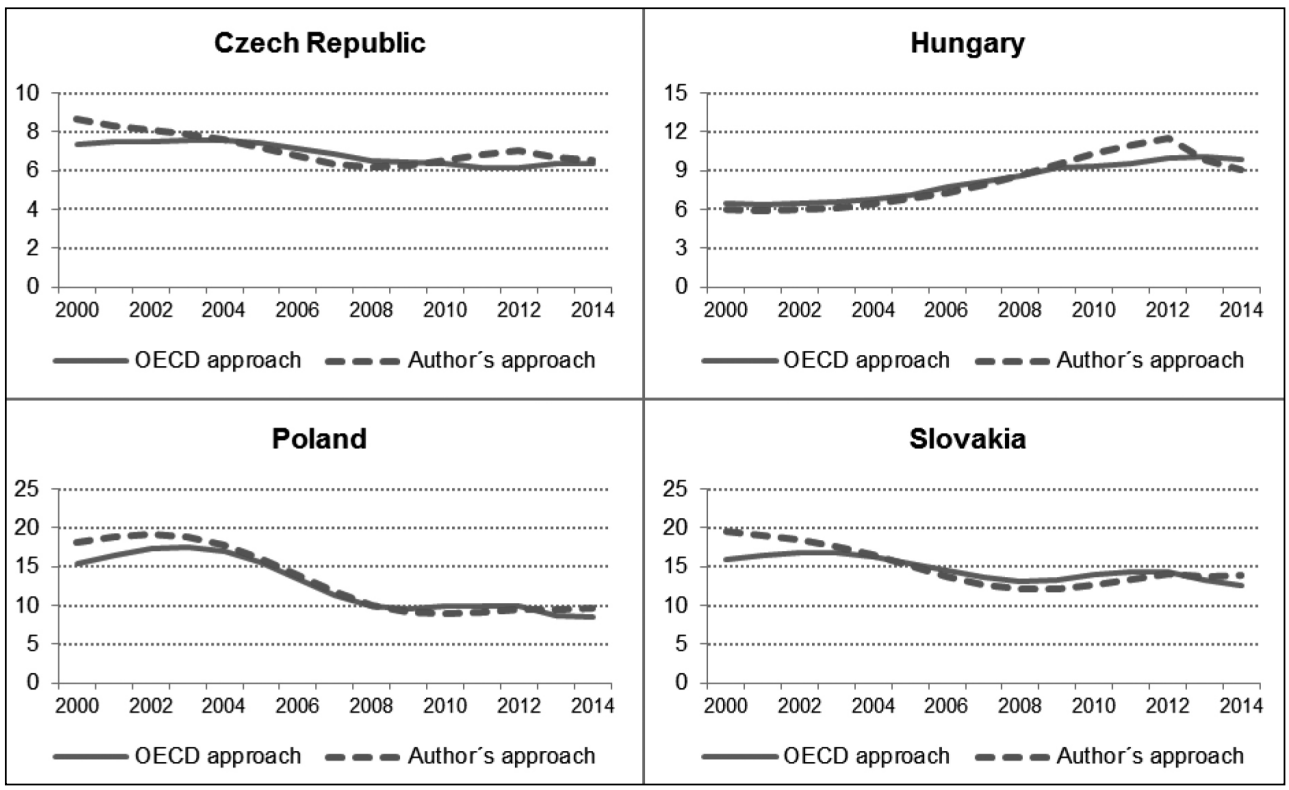

Source: Eurostat and OECD; own calculation 
and increased unemployment, contributed to wage moderation and imposed a cap on jobrich domestic demand growth.

A state-space model (also called the Kalman filter) is another standard methodology employed by the OECD. The Kalman filter, on the other hand, is a multi-variate filter, because in addition to unemployment rate, it facilitates data on other macroeconomic variables that are relevant to the estimation of structural unemployment. In addition, because it uses more information, the Kalman filter has the potential to yield more accurate estimates of structural unemployment and it might help understand the cyclical behaviour of unemployment better if additional variables are added into the dynamic model. Estimated structural unemployment data based on Kalman filter method are available from OECD Statistical Database. Figure 5 shows the comparison of two different approaches to estimate the structural component of unemployment - OECD approach (Kalman filter) and the author's approach based on Flek et al. (2010). Although these are two different approaches, it can be seen from the figure that similar results have been achieved. In other words - it was recorded the similar trend of structural unemployment development.

\section{Conclusion}

The aim of the paper was to perform decomposition of unemployment among Visegrad group countries and to compare two approaches to structural unemployment's estimation. We applied Hodrick-Prescott filter to estimate a trend component of unemployment. Looking at economic performance in the years 2000-2014, measured by the growth rate of real gross domestic product, it is clear that the economies of Visegrad group recorded some phases of the business cycle. All selected economies were influenced by 2009 economic crisis which disrupted significant economic growth and which caused a noticeable decline in real gross domestic product. Our previous studies show that in all observed countries, the unemployment gap was negative due to remarkable economic growth and positive output gap before the crisis which is consistent with economic theory. However, as labour market is a mirror of economic performance, labour market performance measured by the unemployment rate deteriorated after 2008. Based on our estimates, the most important component of unemployment seems to be structural unemployment. This finding is consistent with previous studies. There were both positive and negative cyclical effects. If we look at the rate of structural unemployment it tends to be high although we can see remarkable differences among observed countries. The rate of structural unemployment has decreased in the case of the Czech Republic, Poland and Slovakia. On the other hand, it was increasing in the case of Hungary until 2013. This was mainly due to internal economic problems associated with public finances and government debt. We also compared our approach with an OECD approach which is based on employment of Kalman filter. Results suggest that both methods, although they are based on different processes, lead to analogous results.

The analysis showed considerable sensitivity of these economies to the development of the external environment (except Poland), mainly through an export channel - the most affected was an industry sector, especially automotive industry. It seems to be important to have more diversified structure of the economy, mainly the exports. And if we take into account that the labour market is a mirror of the economic performance, then it is clear that labour markets in these countries react to declines in economic performance relatively quickly. On the other hand, it is a tough task for government to start the recovery of the relatively small and open economy and this might last several quarters while economic downturn might happen during significantly shorter period. As better labour market performance is reliant on economic performance than it is necessary to have optimal setting of labour market institutions (employment protection legislation, active labour market policies or taxation of labour) and also business environment as the economy's anchors. In addition, last surveys show that an essential source for better both economic and labour market performance is labour force and business sector's confidence in the government economic policy and optimistic expectations of future economic development for investment both domestic and foreign. 
The research behind this paper was supported by the Student Grant System within the grant SGS/7/2012 "Influence of Regional Disparities on Business Environment".

\section{References}

Andersson, D.E., Andersson, A.E., Harsman, B., \& Daghbashyan, Z. (2015). Unemployment in European regions: structural problems versus the Eurozone hypothesis. Journal of Economic Geography, 15(5), 883-905. doi:10.1093/jeg/lbu058.

Araújo, S., \& Maleček, P. (2015). The Czech Labour Market: Documenting Structural Change and Remaining Challenges (OECD Economics Department Working Papers No. 1213). Paris: OECD Publishing. doi:10.1787/18151973.

Bakó, T. (2014). The Hungarian labour market in 2012-2013. In K. Fazekas, \& L. Neumann (Eds.), The Hungarian Labour Market 2014. Budapest: Centre for Economic and Regional Studies, Hungarian Academy of Science \& National Employment Non-Profit Public Compacy. Retrieved from http://www. krtk.mta.hu/publications/THE-HUNGARIANLABOUR-MARKET-2014/74/.

Boeri, T., \& Jimeno, J.F. (2015). Unemployment in Europe: What does it take to bring it down? (Working paper). Retrieved May 11, 2015, from https://www. ecbforum.eu/up/ficheiros-bin2_ficheiro_ en_0831068001432737899-95.pdf.

Boone, L. (2000). Comparing Semi-Structural Methods to Estimate Unobserved Variables: The HPMV and Kalman Filters Approaches (OECD Economics Department Working Papers No. 240). doi:10.1787/112875725526.

Chiarini, B., \& Piselli, P. (2001). Identification and Dimension of the NAIRU. Economic Modelling, 18(4), 585-611. doi:10.1016/S02649993(00)00054-7.

Claar, V.A. (2005). Kalman-Filter Approach to Estimating the Natural Rate of Unemployment. In Proceedings of Rijeka School of Economics: Journal of Economics and Business, 23 (pp. 1-24). Rijeka: Rijeka School of Economics.

Egedy, T. (2012). The effects of global economic crisis in Hungary. Hungarian Geographical Bulletin, 61(2), 155-173.

Fabiani, S., \& Mestre, R. (2000). Alternative Measures of the NAIRU in the Euro Area: Estimates and Assessment (ECB Working Paper No.17). Frankfurt: European Central Bank. Retrieved May 20, 2015, from https://www. ecb.europa.eu/pub/pdf/scpwps/ecbwp017. pdf?fb62cab7f4d858d8e52847b202892351.

Fidrmuc, J., Klein, C., Price, R., \& Wörgötter, A. (2013). Slovakia: A Catching Up Euro Area Member. In and Out of the Crisis (IZA Policy Paper No. 55). Retrieved from http://ftp.iza.org/ pp55.pdf.

Flek, V., Marek, D., Niedermayer, L., \& Sobíšek, P. (2010). Vybrané problémy a vyhlídky českého trhu práce. Praha: Česká bankovní asociace. Retrieved from https://www.czech-ba. cz/sites/default/files/down_19553.pdf.

Friedman, M. (1968). The Role of Monetary Policy. American Economic Review, 58(1), 1-17.

Furceri, D., \& Mourougane, A. (2009). How do Institutions Affect Structural Unemployment in Times of Crises? (OECD Economics Department Working Paper No. 730). Paris: OECD Publishing. Retrieved May 12, 2015, from http://www.oecd.org/officialdocuments/ publicdisplaydocumentpdf $/$ ? cote $=E C O /$ WKP\%282009\%2971\&docLanguage=En.

Galgóczi, B., Leschke, J., \& Watt, A. (Eds.). (2009). EU Labour Migration since Enlargement. Trends, Impacts and Policies. Farnham: Ashgate Publishing Limited.

Gerlach, S., \& Yiu, M.S. (2004). Estimating output gaps in Asia: A cross-country study. Journal of Japanese and International Economies, 18(1), 115-136. doi:10.1016/S0889-1583(03)00033-9.

Gersing, A. (1997). Structural Unemployment in Denmark (OECD Economics Department Working Papers No. 183). Paris: OECD Publishing. doi:10.1787/385233524308.

Gianella, C., Koske, I., Rusticelli, E., \& Chatal, O. (2008). What Drives the NAIRU: Evidence from a Panel of OECD Countries (OECD Department Working Paper No. 649). Paris: OECD Publishing. doi:10.1787/231764364351.

Gomes, F.A.R., \& Silva da, C.G. (2009). Hysteresis versus NAIRU and convergence versus divergence: The behavior of regional unemployment rates in Brazil. The Quarterly Review of Economics and Finance, 49(2), 308322. doi:10.1016/j.qref.2007.03.009.

Gómez, V., \& Maravall, A. (1996). Programs TRAMO (Time Series Regression with Arima noise, Missing observations, and Outliers) and SEATS (Signal Extraction in Arima Time Series). Instruction for the User (Working paper No. 9628). Madrid: Banco de España. Retrieved May 11, 2015, from http://www. bde.es/f/webbde/SES/servicio/Programas_ estadisticos_y_econometricos/Programas/ ficheros/manualdos.pdf. 
Gómez, V., Maravall, A. (1998). Seasonal Adjustment and Signal Extraction in Economic Time Series (Working paper No. 9809). Madrid: Banco de España, Retrieved May 14, 2015, from http://www.ccee.edu.uy/ensenian/catmetec/ material/Gomez\%201999\%20Seasonal\%20 Adjustment\%20sasex.pdf.

Hájek, M., \& Bezděk, V. (2001). Odhad potencionálního produktu a produkční mezery v České republice. Politická ekonomie, 50(4), 473-491.

Herz, B., \& van Rens, T. (2011). Structural Unemployment (Working Paper No. 1276). Barcelona: Universitat Pompeu Fabra. Retrieved May 15, 2015, from http://repositori. upf.edu/handle/10230/19871.

Hloušek, M., \& Polanský, J. (2007). Produkční přistup k odhadu potenciálního produktu - aplikace pro ČR. Národohospodářský obzor, 7(4), 3-12.

Maravall, A., \& Sánchez, F.J. (2000). An Application of TRAMO-SEATS : Model Selection and Out-of-Sample Performance: the Swiss CPI Series (Working paper No. 14). Madrid: Banco de España. Retrieved May 27, 2015, from http://www.bde.es/f/webbde/SES/Secciones/ Publicaciones/PublicacionesSeriadas/ DocumentosTrabajo/00/Fic/dt0014e.pdf.

McConnell, C., Brue, S.M., \& Macpherson, D. (2009). Contemporary Labour Economics. Columbus: McGraw Hill.

Němec, D. (2008). Kvantitativní analýza mezery nezaměstnanosti a výstupu v České republice (Working Paper No. 22/2008). Brno: ESF MU, Centrum výzkumu konkurenční schopnosti české ekonomiky. Retrieved May 20, 2015, from http://is.muni.cz/do/1456/soubory/ oddeleni/centrum/papers/wp2008-22.pdf.

OECD. (2014a). OECD Economic Surveys: Hungary 2014. Paris: OECD Publishing. doi:10.1787/eco_surveys-hun-2014-en.

OECD. (2014b). OECD Economic Surveys: Poland 2014. Paris: OECD Publishing. doi:10.1787/eco_surveys-pol-2014-en.

OECD. (2014c). OECD Economic Surveys: Slovak Republic 2014. Paris: OECD Publishing. doi:10.1787/eco_surveys-svk-2014-en.

OECD. (2012). OECD Economic Surveys: Poland. Paris: OECD Publishing. doi:10.1787/ eco_surveys-pol-2012-en.

Orlandi, F. (2012). Structural unemployment and its determinants in the EU countries (Economic Papers 455/May 2012). Brussels: European Commission. doi:10.2765/26367.

Rozmahel, P. (2011). Measuring the business cycles similarity and convergence trends in the Central and Eastern European Countries towards the Eurozone with respect to some unclear methodological aspects. Acta Universitatis Agriculturae et Silviculturae Mendelianae Brunensis, 59(2), 237-250. doi:10.11118/actaun201159020237.

Romer, D. (2005). Advanced Macroeconomics. Boston, MA: McGraw Hill.

Silva Filho da, T.N.T. (2010). The Natural Rate of Unemployment in Brazil, Chile, Colombia and Venezuela: some results and challenges (Working Paper Series No. 212). Brasília: Banco Central do Brasil. Retrieved May 20, 2015, from http://www.bcb.gov.br/pec/ wps/ingl/wps212.pdf.

Šrámková, L. (2010). Output Gapand NAIRU Estimates within State-Space Framework: An Application to Slovakia. Bratislava: Financial Policy Institute, The Ministry of Finance of the Slovak Republic.

Tasci, M. (2012). The Ins and Outs of Unemployment in the Long Run: Unemployment Flows and the Natural Rate (Working Paper No. 12-24). Cleveland, OH: Federal Reserve Bank of Cleveland. Retrieved June 1, 2015, from http://www.clevelandfed.org/research/ workpaper/2012/wp1224.pdf.

Turner, D. et al. (2001). Estimating the Structural rate of unemployment for the OECD Countries (OECD Economic Studies No. 33). Paris: OECD Publishing. Retrieved May 11, 2015, from http://www.oecd.org/eco/ outlook/18464874.pdf.

Tvrdon, M., Tuleja, P., \& Verner, T. (2012). Economic Performance and the Labour Market in the Context of the Economic Crisis: Experience from the Visegrad Four Countries. E\&M Ekonomie a Management, 15(3), 16-31.

Weiner, S.E. (1993). New Estimates of the Natural Rate of Unemplyoment. Federal Reserve Bank of Kansas City Economic Review, 4, 53-69.

Zimková, E., \& Barochovský, J. (2007). Odhad potencionálného produktu a produkčnej medzery v slovenskych podmienkach. Politická ekonomie, 55(4), 473-489.

doc. Mgr. Ing. Michal Tvrdoň, Ph.D. Silesian University in Opava School of Business Administration in Karviná Department of Economics and Public Administration tvrdon@opf.slu.cz 


\section{Abstract}

\section{DECOMPOSITION OF UNEMPLOYMENT: THE CASE OF THE VISEGRAD GROUP COUNTRIES}

\section{Michal Tvrdon̆}

Generally, output measured by real gross domestic product declines and the unemployment rate rises during the economic crisis. This relationship was confirmed in the past several crises. However, the impact of economic downturns on structural unemployment will depend on many factors. The aim of the paper is to decomposite unemployment and we try to estimate the rate of structural unemployment. We also made an effort to determine the effects of the crisis on economic performance and functioning of the labour market in the Visegrad group countries. The analysis showed considerable sensitivity of these economies to the development of the external environment (except Poland), mainly through an export channel - the most affected was an industry sector, especially automotive industry. It seems to be important to have more diversified structure of the economy, mainly the exports. Quarterly data from the Eurostat LFS database in the period between 2000 and 2014 were applied. In order to estimate the trend of the unemployment rate's development was used Hodrick-Prescott filter. Data show that all observed economies recorded a low unemployment rate in a pre-crisis period and they had to face worsened labour market performance during and after the crisis. Our results suggest that structural component seems to be the most important component of total unemployment. Moreover, it has decreased in these countries, except Hungary. We also compared our approach with an OECD approach which is based on employment of Kalman filter. Results suggest that both methods, although they are based on different processes, lead to analogous results.

Key Words: Hodrick-Prescott filter; gross domestic product; NAIRU; structural unemployment.

JEL Classification: C51, E01, E24.

DOI: 10.15240/tul/001/2016-1-001 